\title{
Steve Richards: The Prime Ministers: Reflections on Leadership from Wilson to Johnson; David Runciman: Where Power Stops: The Making and Unmaking of Presidents and Prime Ministers
}

\author{
Atlantic, revised and updated paperback, 2020, 528 pp., ISBN: 978-1786495884; Profile, revised \\ and updated paperback, 2020, 240 pp., ISBN: 978-1788163347
}

\author{
Archie Brown ${ }^{1}$ \\ Published online: 17 August 2021 \\ (C) The Author(s), under exclusive licence to Springer Science+Business Media, LLC, part of Springer Nature 2021
}

\section{Leadership Singular and Plural}

Political leaders are of obsessive interest to journalists, though a far less fashionable object of study for social scientists. Leadership is stubbornly resistant to hypothesis testing, and only some aspects of its study lend themselves to quantification. Yet not everything that counts can be counted. All heads of executive make some difference, and the occasional top leader makes a very great difference-for better or for worse. Thus, it is hardly surprising that books on British prime ministers (and, in far greater numbers, on American presidents) proliferate.

The two discussed here differ in their scope and size and in the background of their authors, but they share certain merits. Steve Richards is one of Britain's best-informed political journalists and David Runciman is a notable scholar, and Professor of Politics at Cambridge, who has pitched much of his writing at a broader public than those in his own discipline. It is the journalist Richards who has written the more substantial, and better documented, book, and the academic Runciman who has produced a much slimmer volume, consisting of a series of 'think-pieces' on particular leaders. His chapters began as review essays published in the London Review of Books. Differences notwithstanding, the books have in common that they are lively, well-written, and stimulating-even when it is disagreement that they stimulate.

Archie Brown

archie.brown@sant.ox.ac.uk

1 Oxford University, Oxford, England
Richards and Runciman offer interesting, but debatable, generalizations about leadership, while devoting most of their chapters to particular leaders. Richards looks at every British prime minister from Harold Wilson (who held the office from 1964 to 1970 and again 1974-1976) to Boris Johnson who succeeded Theresa May as prime minister in July 2019. In his endnotes, Richards refers not only to biographies and memoirs, but to many interviews he himself conducted with prime ministers and other Cabinet ministers, including some, off the record at the time, from which the passage of years has removed the need for anonymity. Just six of Richards's ten prime ministers attract Runciman's attention. These are Margaret Thatcher, Tony Blair, Gordon Brown, David Cameron, Theresa May and, more briefly, Boris Johnson. Interspersed with them, Runciman provides vignettes of American Presidents Lyndon Johnson, Bill Clinton, Barack Obama and Donald Trump.

Neither Richards nor Runciman comes across as hero-worshippers. They see flaws in all the leaders they write about illuminatingly. In varying degrees, however, they follow the fashion to elevate prime ministers far above other members of the government they head. This tendency was given a huge boost by Margaret Thatcher whose premiership helped to promote the myth that the way to 'get things done' was through a prime minister dominating her colleagues and the policy-making process. Her premiership changed British politics more than any ruling party had done since the Labour governments of 1945-1951 pursued egalitarian policies, nationalized public utilities and created the National Health Service and the modern welfare state. That government redefined the limits of the possible in British politics, just as Thatcher's did in the opposite direction a generation later.

Richards refers to 'the presidential culture of British politics and the obsessive focus on leaders and potential leaders' 
(p. 14). His use of 'obsessive' suggests scepticism about that focus. Yet, he does not challenge it. He provides a list of desiderata for prime ministers under the characteristic title, 'The Country is Looking to Elect a Prime Minister' (p. 30). What the country is doing is electing a government, although political commentators and, all too often, politicians themselves frame the choice in these quasi-presidential terms. Yet we are not short of examples of a prime minister resigning (usually against his or her will) and the government continuing without any need for a general election. In that way, Harold Macmillan was succeeded by Sir Alec Douglas-Home, Harold Wilson by James Callaghan, Margaret Thatcher by John Major, Tony Blair by Gordon Brown, David Cameron by Theresa May and May by Boris Johnson. Thus, the notion that it is the prime minister the electorate chooses, rather than the party that will form a government, is as misleading as it is increasingly ubiquitous.

'Only leaders at their peak can be change-makers in policy terms, keeping their party with them and winning the backing of most voters', writes Richards (p. 23). If he were talking about leaders in the plural within a particular government, he might have a point, but it is the leader he has in mind. So the statement should be challenged. The government led by Clement Attlee was one of the two great change-making governments of post-Second World War Britain, that led by Margaret Thatcher being the other. But the modes of leadership were entirely different. Attlee kept a formidable and disparate Cabinet in place, but policy-making was dispersed, and he did not usurp the prerogatives of other ministers.

Attlee gave high priority to keeping a strong team together, one which represented different tendencies within the party. When two Cabinet ministers, Aneurin Bevan and Harold Wilson, resigned in 1951 over their disagreements with Chancellor of the Exchequer Hugh Gaitskell, Attlee was in hospital. He believed that if he had not been ill, he could have succeeded in placating the departing ministers. In his absence, Herbert Morrison, whose relations with Bevan were antagonistic, was temporarily in charge, and he was not sorry to see Bevan depart.

Political and personal disagreements divided several of the biggest players in that Labour team. Foreign Secretary Ernest Bevin disliked Morrison no less intensely than did Bevan. Yet from 1945 to 1951, Attlee kept them all in the Cabinet. Major policies were made by individual leaders and agreed in Cabinet and Cabinet committees. Morrison wielded great influence over domestic policy, and Attlee recognized that Foreign Secretary Bevin, for whom he had vast respect, was the principal foreign policy-maker. Foreign policy is an area where both the speed of communications and international expectations have meant that in more recent decades the head of government can hardly avoid playing the leading role. Domestically, however, contemporary political leaders - of both major parties - should stop being in thrall to Thatcher's style of government. It is far from being a sine qua non for effecting great change. Attlee is rightly regarded as the greatest of Labour prime ministers, not because he was a dominant leader, but because of what his government did collectively after coming to power in extraordinarily difficult circumstances, with the country economically and physically exhausted by the war.

Harold Wilson entered 10 Downing Street in 1964 with comparatively few big policy ideas. Yet much important social reform took place in the second half of the 1960s, including liberalization of the divorce laws, the legalization of homosexual acts between consenting adult males (bringing the law for men into conformity with that for women), abolition of the death penalty and the abolition of censorship in the theatre. These were far more the policies of the Home Secretary Roy Jenkins than of the socially rather conservative Wilson. Richards correctly notes (pp. 64-65) how important it was that Wilson gave Jenkins the space to facilitate these reforms. Along with the major reform of British defence policy by Denis Healey who was a dominant Secretary of State for Defence from 1964 to 1970 and played a key part in keeping the UK out of the Vietnam War, these must rank high among the achievements of the Labour governments of the 1960s.

Richards believes that Harold Wilson has been given less credit as a prime minister than he deserves. He endorses Wilson's own view that his main achievement was to keep his party together. That included working with a Cabinet containing formidable politicians from different points on Labour's left-right spectrum. Prominent among them were Healey, Jenkins, Callaghan, Anthony Crosland, Barbara Castle, Tony Benn and (in the Labour governments of the 1970s) Michael Foot. Six of these seven politicians contested the leadership election when Wilson resigned as Prime Minister in 1976. The only woman among them did not, although Barbara Castle had been a significant member of the Labour government and was popular in the country.

A point to which Richards frequently returns is that a prime minister should be a teacher. He claims that 'at their peak', Harold Wilson, Margaret Thatcher and Tony Blair 'were all political teachers' (p. 16). All three of them in their prime were blessed with an excellent memory and were skilful debaters, leavened by wit in Wilson's and Blair's cases (though not in Thatcher's). But 'teacher' is hardly the most appropriate term. A leader should set the tone of a government and be capable of persuading colleagues of the merits or demerits of a policy and of appealing to a broader public. That is greatly preferable to attempting to pull rank. But persuasion is not pedagogy.

Neither Wilson nor Blair, moreover, was a teacher in any meaningful sense, and Richards is unpersuasive in arguing that a prime minister should be. Both of these Labour prime ministers, as Richards himself notes, talked a lot about 
'modernization', and it was electorally appealing, but the term was vacuous. Blair's most sustained attempt at teaching the British public came as he tried to argue that the terrorist attack on the Twin Towers in New York had changed world politics utterly and as he made the case for the spuriously linked invasion of Iraq. But since pursuit of that policy meant a one-sided approach to the evidence (ignoring the judgements of most British specialists on the Middle East), such skills as Blair exhibited in the pursuit of a disastrous policy were those of a barrister, not a teacher. Margaret Thatcher had more of a claim to be a teacher, because of her deep beliefs in anti-statist, marketizing policies and the fervour with which she proclaimed them.

Her proselytizing anti-Communism and support for dissidents in Communist countries might also qualify, though, against most people's expectations and to the alarm of her own Foreign Policy Adviser, Sir Percy Cradock, she became in the second half of the 1980s an enthusiastic supporter of the General Secretary of the Communist Party of the Soviet Union. Since, however, that Soviet leader, Mikhail Gorbachev, was in the process of making Russia a freer country than it had ever been, she could reasonably argue that there was no inconsistency. On the policy of engagement with the Soviet Union, which the Thatcher government began to pursue in 1983-1984, the Prime Minister was in tune with the Foreign Office (an institution which, however, she continued to disdain) and with a broad swath of the British public. In contrast, though her economic policies had some resonance, they also faced fierce resistance. In domestic politics, Thatcher was an extremely divisive leader, and she left her own party deeply split.

Richards regards 'an indifference to the art of being a political teacher' (p. 355) as one of the problems of Britain's second female prime minister, Theresa May. Divisions over Europe had already bedevilled every Conservative leader from Margaret Thatcher onwards, and, to the extent that problem has been 'resolved' during the premiership of Boris Johnson, it is not because he has been a great teacher. It has been because, behind the façade of bumbling geniality, he has proceeded ruthlessly to force out or marginalize the most pro-European of Conservatives MPs, in the knowledge that he is in line with the sentiments of the ageing constituency of party activists in the country and his backers in the Conservative media.

If May 'had been an effective teacher', writes Richards ( $\mathrm{p}$. 355), 'she would have had more followers, because there would have been a more clearly defined path for them to follow'. Of course, it is a help if a leader is a good story-teller (which May, clearly, was not) who can provide a narrative into which policies can be fitted. But to look to one leader to make policy, and be virtually in sole charge of explaining it, is to import the norms of an autocracy into a democracy. Why, after all, should Members of Parliament be 'followers', rather than politicians with ideas and agency of their own? It is true that they were elected, except in rare instances, not for their personal qualities but because of sufficient support for the party they represented, but their loyalty then should be to that party - and to the current leader only to the extent that he or she is upholding its values, is keeping a strong leadership team together and is not an electoral liability.

It is not often that the personality of a prime minister makes the difference between victory and defeat in a British general election, but most commentators now write as if that were so. When the Conservatives returned to power in 1979, this was not the personal victory of Margaret Thatcher. The 10 Downing Street incumbent James Callaghan was at the time vastly more popular than the Leader of the Opposition. Taking the average of the opinion polls in the last few days of the campaign, Callaghan was some 20 points ahead when voters were asked to compare the party leaders and say which of them would be the better prime minister. The Labour government had, however, struggled through a 'winter of discontent' and industrial strife. The $5.2 \%$ swing from Labour to the Tories was a vote not for Thatcher or against Callaghan, but against Labour, for Callaghan was far more popular not only than Thatcher but also than his party.

Tony Blair never ceases to boast that he "won three elections', but it beggars belief that Labour won those elections only, or even primarily, because of Blair. The Conservative Prime Minister John Major was well aware that a fifth successive general election victory had always been unlikely and that it became a forlorn hope when the party lost its earlier reputation for economic competence once the pound sterling sank like a stone in a currency crisis and fell out of the European Exchange Rate Mechanism (ERM) on 16 September 1992, a day which became known as 'Black Wednesday'. The point was hammered home in what Major describes in his memoirs as 'a brilliant debating performance' by the new Leader of the Opposition John Smith. 'Presented with an open goal', Smith 'joyfully smashed the ball into the net'. ${ }^{1}$

Smith's sudden death from a heart attack at the age of 55 in May 1994, when Labour had an opinion poll lead over the Conservatives of 23 points, was not only a sad day for his party and the country. It has allowed two myths to take root. First, that it was Blair's 'charisma' that enabled Labour to have a landslide victory in the 1997 election and that, linked to this, an essential component of that victory was Blair's attempt to rebrand the party as 'New Labour'. By placing the party in the centre of the existing political spectrum, rather than trying to move the centre in a more radical direction, Labour probably picked up several Conservative seats it would not have won otherwise. However, few people doubted that Labour were on course for a landslide victory during

\footnotetext{
${ }^{1}$ John Major, The Autobiography (HarperCollins, London, 1999), pp. 312 and 339.
} 
Smith's leadership and, subsequently, Blair's. The main exceptions were some Labour MPs (including Blair himself) who had been traumatized by being in Opposition for so long and especially by losing the 1992 election they had expected their party to win.

Richards notes that, rather than providing some uplifting sentiments for the country, Blair's opening gambit outside 10 Downing Street in May 1997 was to define himself against the party people had voted for. Though 'New Labour' never appeared on a ballot paper, and few people knew what it meant, Blair announced, 'We ran for office as New Labour, we will govern as New Labour. This is not a mandate for dogma or for doctrine, or a return to the past' (p. 238). The 'New Labour' term and its content owed much to Peter Mandelson as well as to the example of the centrist Clinton Administration in the USA. In the short run, it doubtless added marginally to the gains Labour was poised to make. In the longer term, it was damaging both because it was divisive within the party and because it caricatured, by implication, the policies of every previous Labour government.

It implied that the party that had created the modern British welfare state, and pragmatically pursued social democratic policies, had been in the grip of dogma. It downgraded the achievements of Attlee, Ernest Bevin, Aneurin Bevan, Herbert Morrison (though he was Mandelson's grandfather), Harold Wilson, James Callaghan and Denis Healey, among other Labour heavyweights, and came close to writing the social advances of the governments in which they served out of history. 'New Labour' was not only, however, a PR stunt. For Blair and some of those close to him -including, up to a point, Gordon Brown who was, successively, Blair's mentor (gifting him his best slogan, 'Tough on crime, tough on the causes of crime'), ally and then rival - it meant a preference for continuing the Thatcher and Major governments' support for extending the involvement of the private sector in public services and an unwarranted assumption that for-profit enterprise was almost invariably more efficient and economical than public enterprise. The Chancellor of the Exchequer in the outgoing Conservative government, Ken Clarke, was later to call this 'Thatcherism with a human face'.

David Runciman is more severe in his critiques of the leaders he discusses than is Richards. He recognizes Bill Clinton as a highly intelligent and skilful tactical politician but dismisses him as 'fundamentally non-strategic' (p. 85). The nearest to an exception from his criticism is Barack Obama whom Runciman admires as a good man with a fine intellect, but he notes (p. 170) that he 'came into politics without deep party ties or a well-established political programme'. $\mathrm{He}$ is disappointed that Obama did not achieve more during his two presidential terms. Obama, doubtless, feels the same, although every day that Donald Trump spent in the White

\footnotetext{
${ }^{2}$ Guardian, 9 April, 2013
}

House was a stark reminder to the rest of us of the value of integrity and decency in a leader. Lyndon Johnson would not necessarily achieve high marks for either of those last two attributes, but, on the criterion of 'deep party ties' and the ability to get things done, few presidents score higher on domestic policy. On foreign policy he was out of his depth, but so were a great many analysts who should have known better than to support the American war in Vietnam - costing some 55,000 American lives and countless more Vietnamese casualties - which ended a decade later with a united Vietnam under Communist rule.

Runciman disagrees with President Johnson's great biographer, Robert A. Caro, that 'power reveals' and that presidential power enabled Johnson to do something he had long wanted to do about combatting racial injustice. Runciman contrasts this with Johnson's past record and is sceptical about his motives. Motivation, however, is a slippery concept and is generally mixed. In spite of (and at times as a result of) his deviousness and bullying, Johnson was able to get civil rights legislation enacted that was beyond the capacity of his predecessor and of the aspirations of most presidents prior to Kennedy. Johnson did have a serious concern with 'levelling up' - to use the favoured terminology of another Johnson (the current British prime minister) who has, however, not moved beyond a rhetorical commitment. And as Runciman writes elsewhere in his book, 'What matters is not who people are. What matters is what they end up doing with the power they have, large or small' (p. 150). As Johnson's presidency drew to a close, the USA recorded its lowest ever inequality gap (as measured by the Gini index), partly as a result of LBJ's 'Great Society' reforms. Even then inequality was higher than for any other democracy for which comparable figures are available, and the inequality gap in the USA has been rising steeply ever since Johnson's departure.

Runciman writes that 'if the result of the turmoil of the past few years is that we end up with less faith in the power of presidents and prime ministers to make all the difference, that will be no bad thing. Maybe what comes after the myth of the strong leader is the idea of leaderless democracy. There are worse ideas' (p. 20). On the first point, he is absolutely right. The expectations placed on presidents and prime ministers are excessive, and a craving for a strong leader is a sign of creeping authoritarianism, not of a mature democracy. 'Leaderless democracy' is another matter. Runciman says there are 'far worse ideas'. No doubt there are. Totalitarian leadership, to name but one, is worse. But there are better alternatives than either one-person domination or 'leaderless democracy'. The latter would rapidly develop into lawlessness, anarchy and the emergence of a new 'strongman'.

Even in city government, not to speak of national politics, leaders are necessary, but at every level, there is much to be said for leadership that is both dispersed and collectivedispersed in the sense that different people are clearly 
responsible for different areas of policy and its implementation, and collective inasmuch as important issues of principle are argued out by the elected ruling group, rather than imposed by the diktat of one person. At national level in Britain, this used to be called individual ministerial responsibility and collective Cabinet responsibility. Their erosion should be resisted. Politicians need to stand up to overmighty party leaders who prefer to concentrate ever more power in their individual hands. (In practice this means that much policy is made by their unelected aides.)

One of the more curious of Runciman's generalizations is that political leaders often arrive in the wrong order. He is sharp in his observation of how Gordon Brown kept low politics and high ideals in separate compartments and, even in his memoirs, as Runciman puts it (p. 119), 'Brown's refusal to acknowledge that politics sometimes entered into his politics can border on the pathological'. But, Runciman writes, 'how different - and potentially how more successful - the New Labour project might have been if Brown had come first and Blair second. Brown's seriousness of purpose would have suited the early period in power, whereas Blair could have injected some glamour and expansive ideas towards the end' (p. 149). For glamour, there is no need to look to prime ministers, nor should we look to a supreme leader to hand down ideas. They are better produced collectively by a group of politicians of high standing in a political party, with the participation of specialists who share their values and provide expertise, and consultation with people experienced in policy implementation at both national and local levels. Runciman's regard for Blair's 'expansive ideas' is hard to square with his dismissal elsewhere of Blair's signature dish of 'deliverology' which he describes as 'a bogus prospectus', since delivery 'depends much more on context than it does on technique' (pp. 172-173).

'What ifs' are of limited value. But for what it's worth, my own preferred 'what if' is that John Smith had not died so terribly prematurely. He would surely have become prime minister in 1997. That Labour government would have benefited from his experience as a Cabinet minister in the administration led by James Callaghan, his far deeper roots in the party than Blair's, his quick-wittedness and his being more relaxed and more collegial than Brown. I have noted elsewhere the observation of an outstanding British civil servant who had a unique opportunity to observe Smith's aptitude not just for politics but for government. Sir Leo Pliatzky was Permanent Secretary at the Department of Trade when Smith was Secretary of State for Trade in 1978-1979 and the youngest member of the Cabinet. In a conversation I had with him when Smith was Leader of the Opposition, Pliatzky said: 'John Smith was a very good minister, and he'll be an even better prime minister'.

\footnotetext{
${ }^{3}$ Archie Brown, The Myth of the Strong Leader: Political Leadership in the Modern Age (Bodley Head, London, and Basic Books, New York, 2014), p. 70
}

Runciman returns to his speculation about order of precedence when he discusses Prime Ministers David Cameron and Theresa May. 'As so often in politics', he remarks, 'the roles seem to have been handed out the wrong way round. May might have been a far better person than Cameron or [George] Osborne to lead the Remain campaign, and had she done so, Britain might still be in the EU: she could have shown the public she took seriously their concerns over immigration. But either Cameron or Osborne might have done a far better job at negotiating Britain's departure' (p. 212). That is fanciful on several different levels. Apart from the logical fallacy entailed by the implication that May would have led the Remain campaign to success, thus obviating the need for Cameron and Osborne to negotiate the terms of departure, the premise that May is a convincing campaigner (apart from knocking on doors in her Maidenhead constituency, at which she is assiduous) will strike anyone who followed her wooden and robotic 2017 election campaign as odd.

Moreover, May failed to heed the advice of Sir Ivan Rogers, the British diplomat with the most intimate knowledge of the workings of, and the people who mattered in, the European Union. Even so, another diplomat Olly Robbins conducted negotiations competently enough on behalf of the government led by May. The problem lay not with the negotiations but with the deep divisions within May's own Cabinet and parliamentary party and her inability to get 'her' deal through the House of Commons. (Essentially Robbins's deal, it would have avoided some of the major problems of that negotiated on Boris Johnson's behalf by the nationalistic and inflexible David Frost.)

Both The Prime Ministers and Where the Power Stops are entertaining, informative and provocative books and well worth reading. Richards, in particular, provides a lot of detailed insight into the workings of British politics. He concludes by observing that prime ministers, having risen to the top of the greasy pole, feel very special, but then they discover 'the wretched powerlessness of power' (p.451). For his part, Runciman notes a tendency of leaders to succumb to the myth that 'they could get things done by sheer force of political will' (p. 19).

That they will encounter events, problems and crises over which they have only very limited control is undoubted. The coronavirus crisis has been a spectacular case in point. It has tested the governmental capacity of every country and their political and scientific leaderships. In both the USA and the UK, the top leader fell short. By several criteria, especially per capita mortality rates, Donald Trump and Boris Johnson presided over two of the least successful responses to the pandemic in the developed world. After great human and economic damage was inflicted, both countries were partially rescued by their scientific capacity and, in the British case, by the National Health Service, not least its efficient delivery of the mass vaccination programme. 
However, in significant respects, prime ministers and presidents are not as powerless as, in the case of British premiers, Richards suggests they are. I would argue that their power of appointment, presumption that they are entitled to take all the big decisions, and veto power over policy are greater than is healthy for a democracy. The sooner political leadership is seen as a collective, rather than individual, endeavour, the better. Paradoxical though it sounds, singular leadership is rarely the product of single-person domination but is the shared accomplishment of a plurality of leaders.
Publisher's Note Springer Nature remains neutral with regard to jurisdictional claims in published maps and institutional affiliations.

Archie Brown is Emeritus Professor of Politics at Oxford University. His books include The Myth of the Strong Leader (2014) and, most recently, The Human Factor: Gorbachev, Reagan, and Thatcher, and the End of the Cold War (2020). 